\title{
Measurements of 234U and 238U in Hair, Urine, and Drinking Water Among Drilled Bedrock Well Water Users for the Evaluation of Hair as a Biomonitor of Uranium Intake
}

Axel Israelsson and Håkan Pettersson

\section{Linköping University Post Print}

\section{Tweet}

N.B.: When citing this work, cite the original article.

Original Publication:

Axel Israelsson and Håkan Pettersson, Measurements of 234U and 238U in Hair, Urine, and Drinking Water Among Drilled Bedrock Well Water Users for the Evaluation of Hair as a Biomonitor of Uranium Intake, 2014, Health Physics, (107), 2, 143-149.

http://dx.doi.org/10.1097/HP.0000000000000075

Copyright: Lippincott, Williams \& Wilkins http://www.lww.com/

Postprint available at: Linköping University Electronic Press

http://urn.kb.se/resolve?urn=urn:nbn:se:liu:diva-108889 


\section{MEASUREMENTS OF ${ }^{234}$ U AND ${ }^{238}$ U IN HAIR, URINE AND DRINKING WATER AMONG DRILLED BEDROCK WELL WATER USERS FOR THE EVALUATION OF HAIR AS A BIOMONITOR OF URANIUM INTAKE.}

Axel Israelsson ${ }^{1}$ and Håkan Pettersson ${ }^{2}$

\footnotetext{
${ }^{1}$ Radiation Physics, Department of Medical and Health Sciences, Linköping University, Linköping SE 581 85, Sweden.

${ }^{2}$ Radiation Physics, Department of Medical and Health Sciences, Linköping University, Department of Radiation Physics, Center for Surgery, Orthopaedics and Cancer Treatment, County Council of Östergötland, Linköping, SE 581 85, Sweden.
} 


\begin{abstract}
Hair is evaluated and compared with urine as biomonitor for human intake of uranium.

Concentrations of ${ }^{234} \mathrm{U}$ and ${ }^{238} \mathrm{U}$ and the activity ratio between them are measured in the hair, urine and drinking water of 24 drilled bedrock well water users in Östergötland, Sweden. The samples are measured with $\alpha$-spectrometry after radiochemical preparation using liquid-liquid separation with tributylphosphate.

The results show that there is a stronger correlation between the uranium concentrations in the drinking water of each subject and the hair of the subject $\left(\mathrm{r}^{2}=0.50\right)$ than with the urine $\left(\mathrm{r}^{2}=0.21\right)$. There is also a stronger correlation between the activity ratios of water and hair $\left(\mathrm{r}^{2}\right.$ $=0.91)$ than between water and urine $\left(r^{2}=0.56\right)$. These results imply that hair may serve as a robust indicator of chronic uranium intake. One obvious advantage over sampling urine is that hair samples reflect a much longer excretion period; weeks compared to days.

The absorbed fraction of uranium, the $f$ value, is calculated as the ratio between the excreted amount of uranium in urine and hair per day and the daily drinking water intake of uranium. The $f$ values stretch from 0.002 to 0.10 with a median of 0.023 .
\end{abstract}




\section{INTRODUCTION}

Studies on the intake levels of natural radionuclides are performed in order to assure that individuals are not exposed to elevated levels. The excretion in urine is often used as a measure, but scalp hair has also been discussed as a possible biomonitor for certain radionuclides.

Uranium is a primordial alpha-emitting heavy metal found mainly in granites and pegmatites in minerals such as oxides, phosphates, carbonates and silicates. The species of uranium found in ground water vary depending on source material, physical and chemical parameters controlling the release, $\mathrm{pH}$ value, reduction potential and the character and flow parameters of aquifers. Drinking water from drilled bedrock wells in Finland has shown a predominance of calcium uranyl carbonates (Prat et al. 2009). As part of radioactive decay series, uranium is usually found together with its decay products in drinking water. Intake of radium, thorium, polonium and radon generally contribute more to radiation dose than uranium (Isam Salih et al. 2002, Jia et al. 2009). Epidemiological studies on intake of naturally radioactive water have shown evidence of uranium nephrotoxicity (Wrenn et al. 1985) and radium bone carcinogenicity (Finkelstein and Kreiger 1996). Animal studies have shown association between uranium in kidneys and renal metabolism of xenobiotics and vitamin D- and iron-homeostasis. Furthermore, uranium-induced oxidative stress and alteration of gene expression in metabolic pathways, cell signaling, and trafficking, has been reported. There is also a documented association between uranium concentration in drinking water and indicators of bone resorption (Canu et al. 2011).

The World Health Organization (WHO) guideline value for uranium in drinking water is $0.03 \mathrm{mg} \mathrm{l}^{-1}$, which is based on its chemical toxicity. The guidance level for ${ }^{238} \mathrm{U}$ and ${ }^{234} \mathrm{U}$ are $10 \mathrm{~Bq}^{-1}$ and $1 \mathrm{~Bq}^{-1}$ respectively, which serves to assure that the annual dose from drinking water does not exceed $0.1 \mathrm{mSv}$ to members of the public (WHO 2011). The world average concentration of ${ }^{238} \mathrm{U}$ in drinking water is $1 \mathrm{mBq} \mathrm{kg}^{-1}$ (UNSCEAR 2000). At these moderate levels, the majority of ingested uranium in an individual usually stems from food intake. However, drinking water derived from private wells may show much higher uranium concentrations. In southern Finland the concentration among 215 users of private water were $0.02-1770 \mu \mathrm{g} \mathrm{kg}^{-1}$ with a mean of $18.1 \mu \mathrm{g} \mathrm{kg}^{-1}\left(0.23 \mathrm{~Bq} \mathrm{~kg}^{-1}\right.$ of $\left.{ }^{238} \mathrm{U}\right)$ (Muikku et al. 2009). A study performed in the same area as the present study comprising of 318 drilled bedrock wells resulted in uranium concentrations of $2.2-425 \mu \mathrm{g} \mathrm{kg}^{-1}$ with a mean of $14.2 \mu \mathrm{g} \mathrm{kg}^{-1}(0.18 \mathrm{~Bq}$ $\mathrm{kg}^{-1}$ of ${ }^{238} \mathrm{U}$ ) (Isam Salih et al. 2002). This corresponds to an annual intake of approximately $100 \mathrm{~Bq}{ }^{238} \mathrm{U}$, assuming a water consumption of $1.5 \mathrm{l} /$ day. If compared to data obtained from a European study on uranium in foodstuffs (EFSA 2009), in which uranium concentrations of typical food baskets in 17 countries are compiled, one can conclude that intake by water here likely was the predominant source of uranium intake; For a person weighting $70 \mathrm{~kg}$, the tabulated values result in a calculated annual median overall foodstuffs intake of about only 8 $\mathrm{Bq}^{238} \mathrm{U}$.

In order to properly determine the dose resulting from ingestion of water containing uranium, knowledge about the uranium isotopic composition is important. In such assessments secular equilibrium between ${ }^{238} \mathrm{U}$ and ${ }^{234} \mathrm{U}$ is often simplistically assumed (UNSCEAR 2000) (Spencer et al. 1990), ignoring that ${ }^{234} U$ is usually elevated versus ${ }^{238} U$ in ground water and bedrock well water (Ivanovich and Harmon 1982, Isam Salih et al. 2002, Karpas et al. 2005b). This implies that for the same amount of uranium in $\mu \mathrm{g} \mathrm{l}^{-1}$ the total uranium activity concentration may be more than double that of equilibrium. Another aspect of the activity ratio ${ }^{234} \mathrm{U} /{ }^{238} \mathrm{U}$ is that it may serve as a signature of exposure sources after intake. However, analysis of ${ }^{234} \mathrm{U}$ at $\mathrm{mBq}^{-1}$ levels requires sensitive radiometric analysis, e.g. by radiochemical separation followed by alpha spectrometry. Analysis by inductively coupled 
plasma mass spectrometry (ICP-MS) may suffice if an efficient nebulization device is connected to the ICP-MS (Karpas et al. 2005b).

In order to properly assess the radiation exposure from uranium intake, the absorption factor, $f$, i.e. the fraction of ingested uranium that is transferred to the blood, is essential. The International Commission on Radiological Protection (ICRP 1995) propose an absorption factor for members of the public of 0.02 (adult non-occupational). Studies have, however, shown values of $f$ ranging from 0.009 (Zamora et al. 2002) to 0.20 (ICRP 1979) with the latter proposed for uranium in organically complexed food. The compartment model proposed by (ICRP 1995) shows the transfer and retention in different body parts. It can be used for dose calculations in software such as IMBA (Birchall et al. 2003) or SAAM II (Barrett et al. 1998). However, the model does not include hair as an excretion pathway. Li has proposed a revised model to include the hair compartment ( $\mathrm{Li}$ et al. 2009). Uranium excretion in hair has been described in several studies (Gonnen et al. 2000, Rodushkin and Axelsson 2000, Mohagheghi et al. 2005, Karpas et al. 2005a, Akamine et al. 2007, Muikku et al. 2009, D'Ilio et al. 2010, Kehagia et al. 2011, Zunic et al. 2012). One advantage of it may be the possibility to use hair shafts for chronological studies as the uranium is stored inside the hair. This has been done using laser ablative (LA-) ICP-MS (Elish et al. 2007). Preliminary studies using micro $\mathrm{x}$-ray fluorescence $(\mu-\mathrm{XRF})$ conducted by the authors have also shown promising results in this regard.

In the present paper a study on the excretion of uranium in hair and urine in relation to the intake from drinking water is performed on 24 drilled bedrock well water users. Hence, the exposure is natural and relevant to members of the public. The hypothesis tested here is that the hair is more reliable as an indicator of chronic uranium exposure than urine. By using alpha spectrometry ${ }^{234} \mathrm{U}$ (and ${ }^{238} \mathrm{U}$ ) activity is measured with high precision. Validation of the intake is then performed by determination of the isotope ratio ${ }^{234} \mathrm{U} /{ }^{238} \mathrm{U}$. Taking hair as excretion pathway into account, $f$ value calculations are performed.

\section{MATERIALS AND METHODS}

\section{Sampling program and sample preparation}

Inhabitants of Östergötland county, Sweden, with water supply from drilled bedrock wells have previously participated in a study of their drinking water (Isam Salih et al. 2002). Hence, for the present study 24 volunteers were selected from the sites where a high uranium concentration in water was found. The subjects were 46-79 years old (median 65 years) and had used their wells for 15-50 years (median 22 years). Each subject was asked to estimate the fraction of their water intake that typically comes from their well. This fraction is here called usage fraction, $k_{u}$, and is shown in table 1 . Water, urine and hair samples were collected. After running for 20 seconds, cold water, about 5 l, was taken from the kitchen tap and stored in plastic cans. The urine samples were collected over a $24 \mathrm{~h}$ period and each was stored in a plastic can. Both urine and water samples were stored in acidic condition $(0.1 \mathrm{M} \mathrm{HCl})$. The hair samples, about $0.5 \mathrm{~g}$, were cut from the back of the scalp. The sample amounts used for analysis were approximately $1 \mathrm{~kg}$ of water, $0.2 \mathrm{~kg}$ of urine and $0.2 \mathrm{~g}$ of hair. The hair length varied from 5 to $200 \mathrm{~mm}$ between individuals.

The hair and urine samples were stored frozen prior to analyses. The hair samples were pre-prepared for analysis by thorough sequential washing in order to eliminate exogenic uranium. The sample was put in a $100 \mathrm{ml}$ syringe filled with detergent (Triton-X of $1 \%$ concentration) for 12 hours. The syringe with its content was thereafter put in an ultrasonic bath for $30 \mathrm{~min}$ with $55^{\circ} \mathrm{C}$ water as wave transport medium. The detergent was then cleared from the syringe through a filter to keep the hair inside the syringe. The sample was rinsed with two flushes of demineralized water and one of acetone and lastly it was dried. 
Table 1. The activity concentration of ${ }^{234} \mathrm{U}$ and ${ }^{238} \mathrm{U}$ and the ${ }^{234} \mathrm{U} /{ }^{238} \mathrm{U}$ activity ratio in water, urine and hair for each subject is given. The uranium concentration in water, the $f$ value and the usage factor are also given. 'A' corresponds to a female and ' $B$ ' to a male subject.

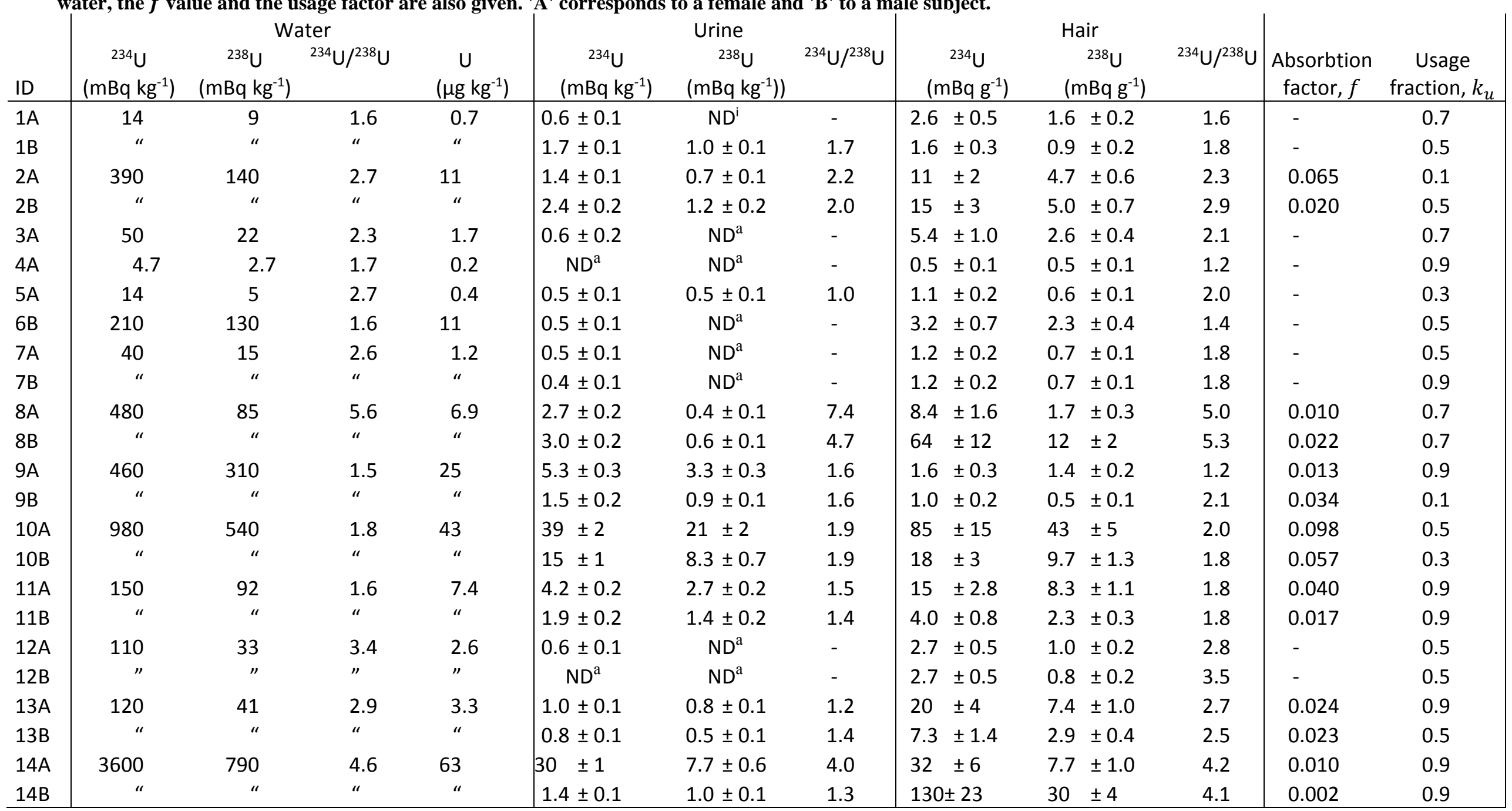

${ }^{a}$ Not detected. Below detection limit. 


\section{Analytical methods}

Prior to radiochemical analysis traceable amounts of ${ }^{232} \mathrm{U}$ yield determinant was added to the samples. The water and urine samples were allowed to evaporate to near dryness on a hot plate before digestion in conc. $\mathrm{HNO}_{3}$ and aqua regia. The hair was digested in conc. $\mathrm{HNO}_{3}$ on a hot plate. The separation of uranium was performed by liquid-liquid extraction with tributyl phosphate (TBP) from a $8 \mathrm{M} \mathrm{HNO}_{3}$ sample solution (Holm 1984). Competing actinides were thereafter removed from the TBP diluted in xylene by back-extraction in $5 \mathrm{M} \mathrm{HCl}$. Finally uranium was back-extracted from TBP in demineralized water. The water phase was then evaporated to dryness after addition of $1 \mathrm{ml}$ of $0.3 \mathrm{M} \mathrm{NaSO}_{4}$. The remaining salt was dissolved in concentrated $\mathrm{H}_{2} \mathrm{SO}_{4}$. The chemical yield of the radiochemical method for the sample matrices is typically $60-80 \%$. All chemicals used were Pro Analysis quality from Merck.

\section{Analysis}

Uranium was electrodeposited onto stainless steel discs using the method as described by Hallstadius (Hallstadius 1984). Alpha measurements were then performed using an Ortec Octête Plus alpha spectrometer equipped with Ametek - Ultra ${ }^{\mathrm{TM}}$ Alpha detectors. Typical counting times were 1-2 weeks.

The absorption factor $f$ was calculated as

\section{ABSORPTION FACTOR, $\boldsymbol{f}$}

$$
f=\frac{c_{u} \times m_{e x c, u}+c_{h} \times m_{e x c, h}}{c_{w} \times m_{\text {ing,w }} \times k_{u}}
$$

where $c$ is the concentration of uranium measured in urine, hair and water and $m$ is the respective mass excreted or ingested during a day. The assumption that the mass of water ingested is equal to the mass of urine excreted, $m_{\text {exc }, u}=m_{\text {ing,w }}$, was made. An additional assumption that each participant produces $0.1 \mathrm{~g}$ hair per day was also made (Karpas et al. 2005a). The usage fraction, $k_{u}$, was used to adjust the water intake to include only their well water. In order to avoid significant contribution of uranium intake from food in the evaluation, only subjects with a uranium concentration in their drinking water exceeding $3 \mu \mathrm{g}$ $\mathrm{kg}^{-1}$ were included in the calculation.

\section{RESULTS}

The measured concentrations of ${ }^{234} U$ and ${ }^{238} U$ and the ${ }^{234} U /{ }^{238} U$ activity ratio in water, urine and hair for all volunteers are listed in Table 1. The concentrations in 8 urine samples were below the Lower Limit of Detection (LLD). These subjects were therefore excluded from the correlation coefficient and $f$ value calculations and in the figures presented. All subjects had a concentration of uranium in their drinking water exceeding the world-wide average level of 1 $\mathrm{mBq} \mathrm{kg}{ }^{-1}$ with the lowest being 4.7, the highest 3590 and median $150 \mathrm{mBq} \mathrm{kg}^{-1}$. Only one household out of 14 had a uranium concentration exceeding the WHO guidance level of $1 \mathrm{~Bq}$ $1^{-1234} \mathrm{U}$ in water. Two households exceeded the uranium guideline value set by WHO of 0.03

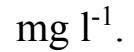

Fig. 1 shows the ${ }^{234} U$ activity concentrations in urine and hair as functions of the concentration in the household water for each individual. Hair has a stronger correlation with water intake than urine, $\mathrm{r}^{2}$ being 0.50 for hair and 0.21 for urine.

Fig. 2 shows the ${ }^{234} U /{ }^{238} U$ activity ratios for the urine and hair samples from each individual versus the activity ratio of their drinking water. The activity ratios of the hair 
samples show a significantly higher correlation with the ratios of the drinking water than those of the urine samples, $\mathrm{r}^{2}=0.91$ and $\mathrm{r}^{2}=0.56$, respectively. The mean value of the ${ }^{234} \mathrm{U} /{ }^{238} \mathrm{U}$ activity ratios are $2.7,2.5$ and 2.3 for water, hair and urine respectively.

The calculated $f$ values are plotted in fig. 3 . They range from 0.002 to 0.1 with a median value of 0.023 . The fraction of absorbed uranium excreted per time unit in the hair to total excreted uranium was, on average, $31 \%$ (median $20 \%$ ) with a standard deviation of $25 \%$.

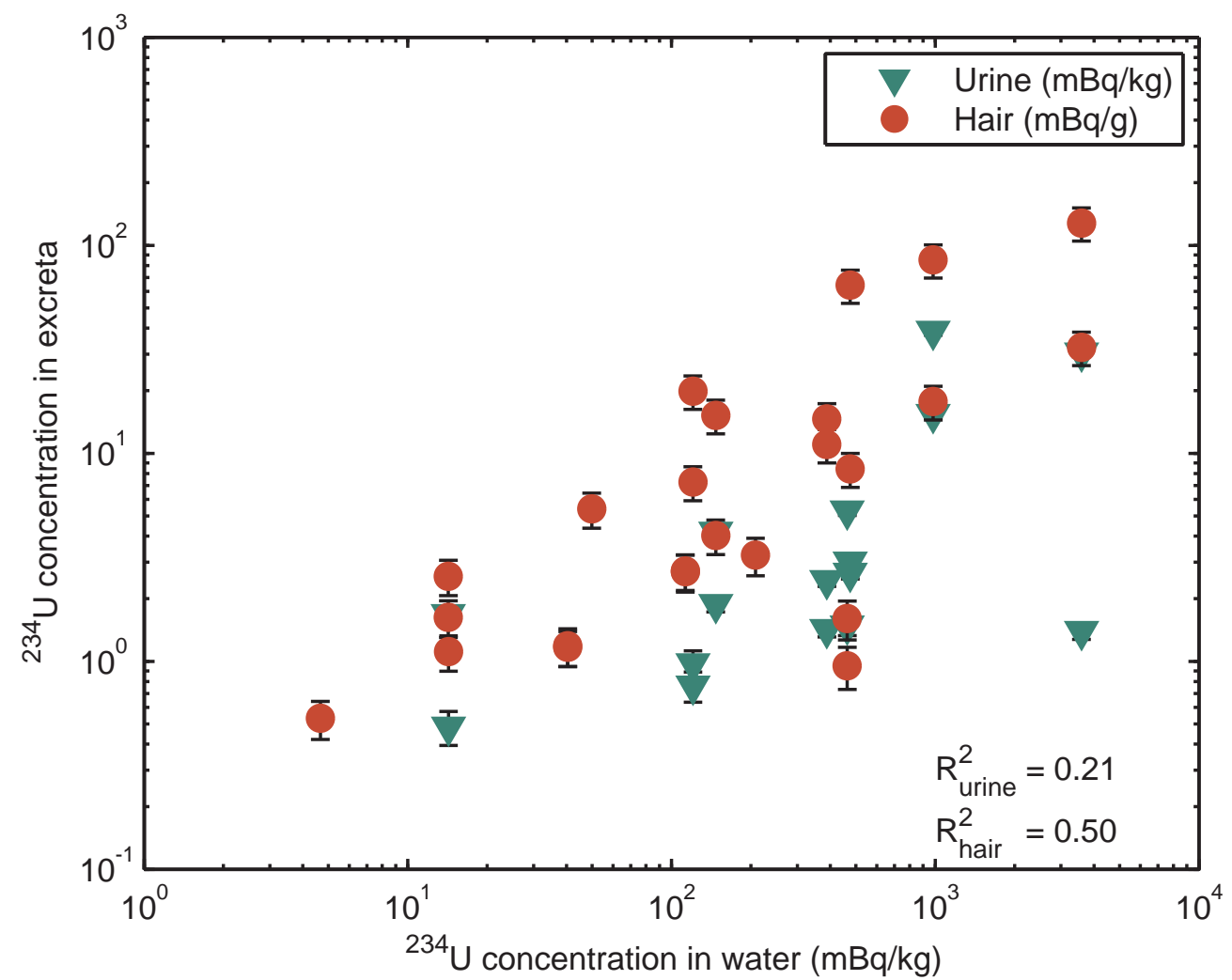

Figure 1. The activity concentration of ${ }^{234} U$ in excreted urine and hair as a function of the ${ }^{234} U$ concentration in the drinking water. 


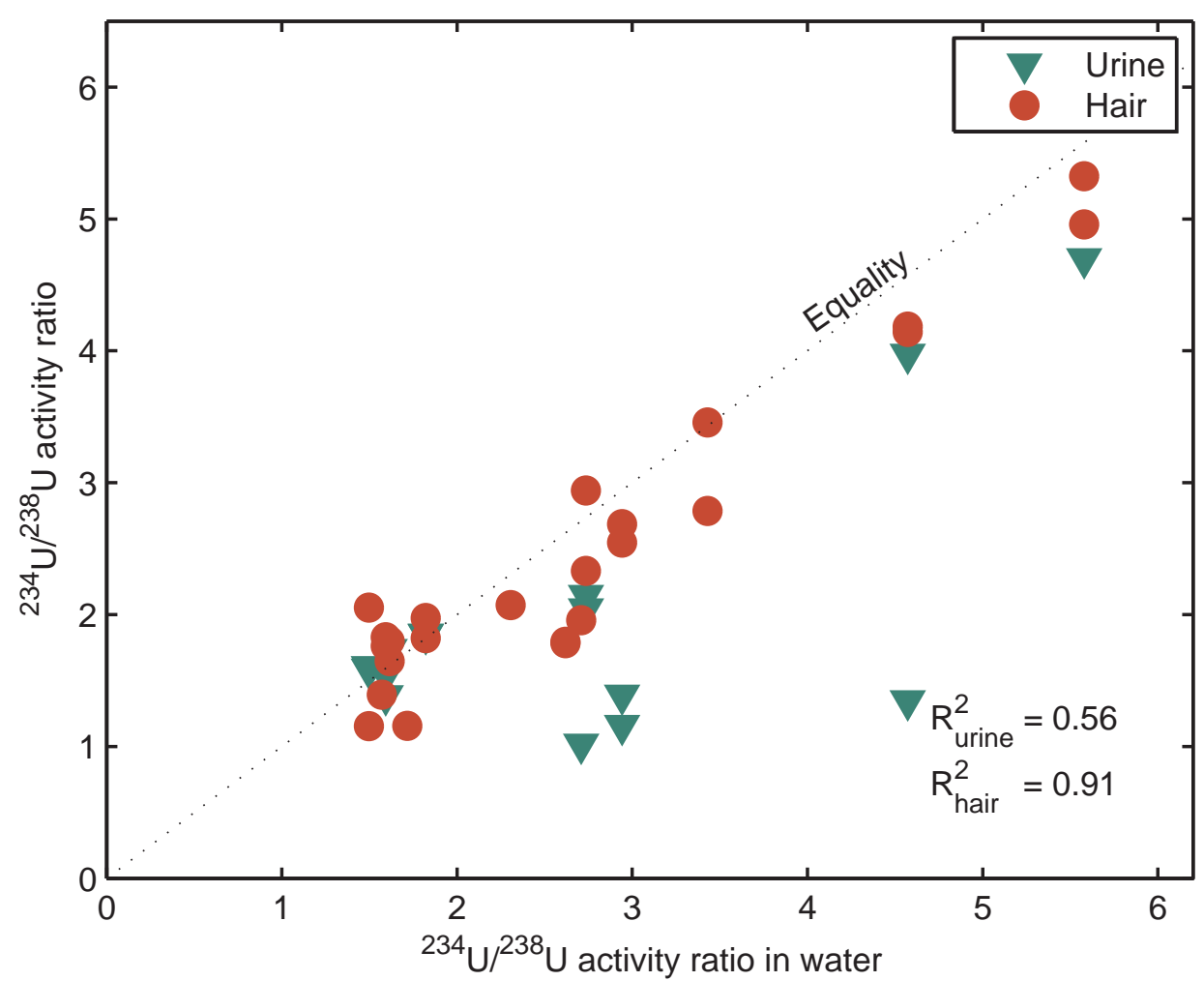

Figure $2 .{ }^{234} U /{ }^{238} U$ activity ratios for the urine and hair samples from each individual as a function of the ${ }^{234} \mathrm{U} /{ }^{238} \mathrm{U}$ activity ratio of their drinking water.

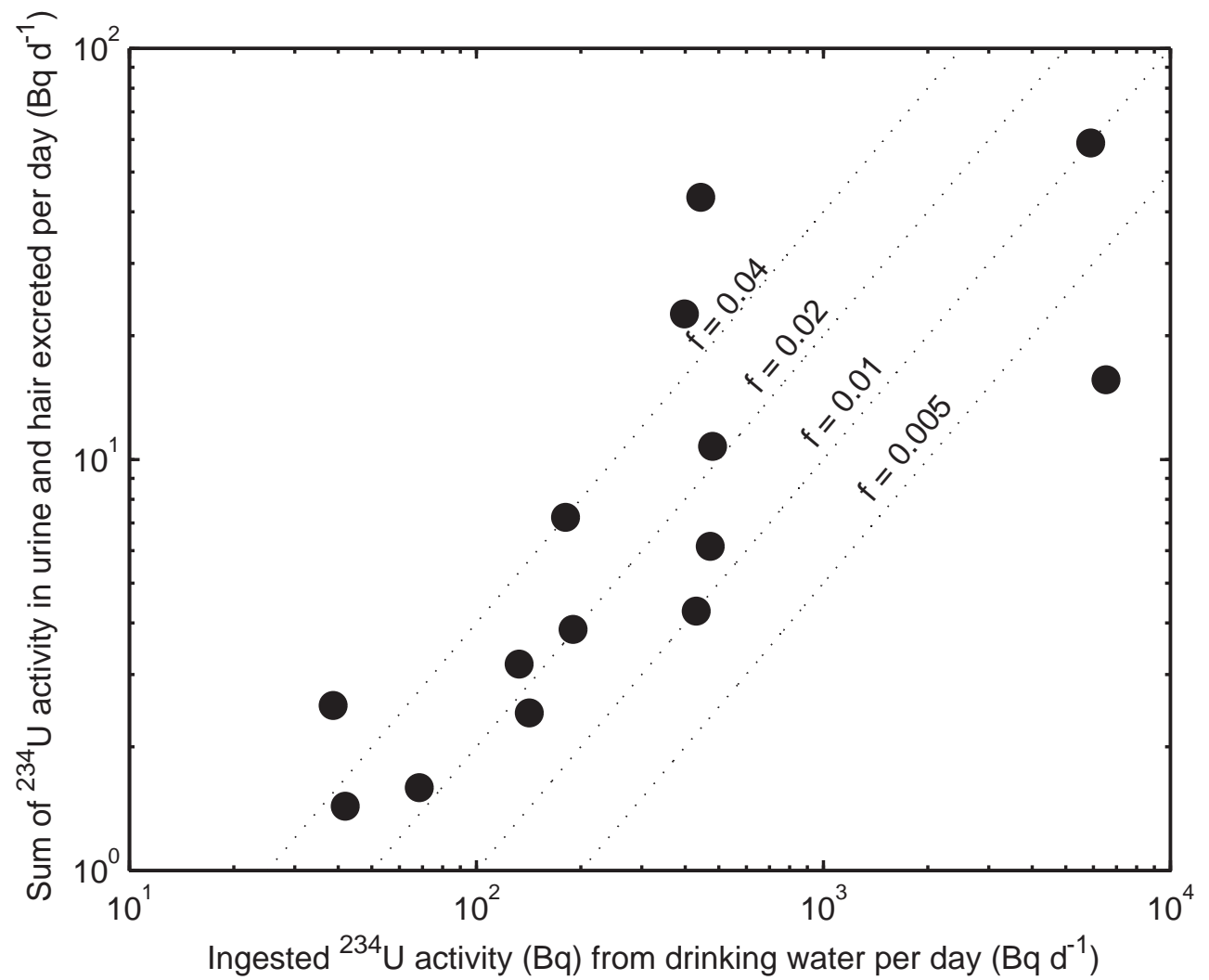

Figure 3. Total ${ }^{234} U$ excreted per day as a function of ${ }^{234} U$ intake through drinking water. Lines indicating $\boldsymbol{f}$ values of $0.04,0.02,0.01$ and 0.005 are plotted. 


\section{DISCUSSION}

The measured concentrations of ${ }^{238} \mathrm{U}$ and ${ }^{234} \mathrm{U}$ were higher than the world-wide average level, but not unusually high given the geographical position, the geology and the type of water supply. Granite bedrock is common in Sweden and the Östergötland County, and it is known to often result in elevated uranium concentrations in ground water. The isotopes ${ }^{238} \mathrm{U}$ and ${ }^{234} \mathrm{U}$ were shown to be in disequilibrium at all sites; the ${ }^{234} \mathrm{U} /{ }^{238} \mathrm{U}$ activity ratios ranged from 1.5 to 5.6 .

As expected, the ${ }^{234} \mathrm{U}$ activity concentration in the hair and urine samples increased with increasing ${ }^{234} \mathrm{U}$ concentration in the drinking water. As seen in fig. 1 the correlation is stronger between the ${ }^{234} U$ concentrations in water and hair than between water and urine. This implies that the measured ${ }^{234} \mathrm{U}$ concentration in hair better reflects the ${ }^{234} \mathrm{U}$ intake, assuming that the main intake of uranium is via drinking water. Such an assumption is reasonable when the concentration in the drinking water is above a few $\mu \mathrm{g}^{-1}$ (Karpas et al. 2005a). Apart from intake of water as cold and warm drinks prepared with the well water, ingesting solid foods such as potatoes and pasta boiled in the water results in uranium intake.

Fig. 2 shows how the ${ }^{234} U /{ }^{238} U$ ratios of hair are closer to being equal with the ratios of drinking water than the ones of urine are. The urine evidently, to a larger extent, has a component of uranium with lower ${ }^{234} \mathrm{U} /{ }^{238} \mathrm{U}$ activity ratio mixed with the uranium from the drinking water $\left({ }^{234} \mathrm{U} /{ }^{238} \mathrm{U}>1.5\right)$. One reason for this could be that the uranium in solid food and liquids with differing chemical form have different absorption properties and are transported differently inside the body. Solid food can here be assumed to have a lower activity ratio and may be more prone to be excreted in urine (Swedish foodstuff mainly contain uranium with ${ }^{234} \mathrm{U} /{ }^{238} \mathrm{U}$ activity ratio close to one. However, dairy products and meat may have a ratio higher than unity. Another reason could be that the hair contains a fraction of uranium that is not endogenous, but is absorbed rather into the shafts from e.g. showering and bathing using water from the private well. This has been mentioned by (Leggett et al. 2012) and (Muikku and Heikkinen 2012). However, hair is well known as an excretion pathway for numerous other substances. How large the fraction of exogenous uranium that remains after thorough washing needs to be investigated further, but is beyond the scope of this article.

The hair samples consist of strands longer than $5 \mathrm{~mm}$. Assuming a typical growth rate of 10-15 mm per month (Krause and Foitzik 2006) they reflect the excretion over more than 2 weeks. The urine samples are collected as daily urine and conversely reflect the excretion over only one day. The hair shows the uranium concentration as a mean value over time, which is advantageous considering that the intake of uranium is often somewhat irregular. Hair is therefore preferable as a monitor of chronic exposure.

$f$ value calculations are often based on the assumption that the fraction of uranium absorbed into the blood that is not eventually excreted in the urine is negligible (ICRP 1995, Zamora et al. 2002). The $f$ value calculations in the present paper are based on the excretion in both urine and hair. The $f$ values show a large variation between individuals as seen in fig. 3. One $f$ value, at 0.002 , is considerably lower than the others. As seen in table 1 it belongs to subject 14B, which has a very low uranium excretion in urine in relation to the assumed uranium intake in water. The ${ }^{234} \mathrm{U} /{ }^{238} \mathrm{U}$ activity ratio of his urine also differs significantly from the ones of the water and hair. There is reason to believe that this subject has not ingested well water the day or two prior to sample collection. The fraction of the $f$ value attributed to hair excretion was $30 \%$ on average, but the inter-individual variation was large. Growth rate, hair type and color are important factors that come into play as well as the variation in the fraction of well water intake to total water intake.

The comparison between hair and urine as biomonitors of uranium intake also requires a qualitative perspective along with the quantitative described above. The possibility to use hair 
for chronological evaluations, i.e. to determine the uranium concentration as a function of time, is a great advantage. Segmenting the shafts manually or scanning them with LA-ICPMS or $\mu$-XRF, which are promising methods, could yield information on the uranium excretion for as short a period as a few days. Depending on the length of the hair, it may be possible to determine the excretion rate months or even years back. A long term variation of the intake as well as an accidental exposure of a short period can be identified. An interesting example on how single hair strands were used to determine the exposure chronology after mercury and a platinum intake is described by Stadlbauer (Stadlbauer et al. 2005). Another advantage with the usage of hair instead of urine is the feasibility in sample collection and handling; about $0.2 \mathrm{~g}$ of hair versus about $1 \mathrm{~kg}$ of urine.

\section{CONCLUSION}

This study shows that hair is a satisfactory alternative to urine for monitoring chronic uranium intake by ingestion. The concentration of uranium in the analyzed hair samples shows a better correlation with the concentration in the subjects' drinking water than the concentration of urine. The ${ }^{234} \mathrm{U} /{ }^{238} \mathrm{U}$ activity ratios obtained also point to the fact that hair better reflects chronic intake of uranium than urine does. The results of the $f$ value calculations were in accordance with the values proposed by ICRP although an increase was seen when adding hair excretion to the calculation.

\section{ACKNOWLEDGEMENT}

The authors would like to thank Ylva Ekholm and Marie Carlsson for their assistance in sampling and sample preparations. This work was kindly supported in part by funding from the Medical Research Council of Southeast Sweden. 


\section{REFERENCES}

Akamine AU, Duchen Silva MA, Saiki M, Vasconcellos MBA, De Andrade SL, Fulfaro R. Determination of uranium in human head hair of a brazilian populational group by epithermal neutron activation analysis. Journal of Radioanalytical and Nuclear Chemistry 271: 607-609; 2007. DOI: 10.1007/s10967-007-0315-x

Barrett PHR, Bell BM, Cobelli C, Golde H, Schumitzky A, Vicini P, Foster DM. Saam ii: Simulation, analysis, and modeling software for tracer and pharmacokinetic studies. Metabolism 47: 484-492; 1998. DOI: 10.1016/S0026-0495(98)90064-6

Birchall A, Puncher M, James AC, Marsh JW, Jarvis NS, Peace MS, Davis K, King DJ. Imba expert $^{\mathrm{TM}}$ : Internal dosimetry made simple. Radiat Prot Dosim 105: 421-425; 2003. DOI: 10.1093/oxfordjournals.rpd.a006273

Canu IG, Laurent O, Pires N, Laurier D, Dublineau I. Health effects of naturally radioactive water ingestion: The need for enhanced studies. Environ Health Persp 119: 16761680; 2011. DOI: 10.1289/ehp.1003224

D'Ilio S, Violante N, Senofonte O, Majorani C, Petrucci F. Determination of depleted uranium in human hair by quadrupole inductively coupled plasma mass spectrometry: Method development and validation. Analytical Methods 2: 1184-1190; 2010. DOI: 10.1039/c0ay00276c

EFSA. Scientific opinion. Uranium in foodstuffs, in particular mineral water. Scientific opinion of the panel on contaminants in the food chain. European Food Safety Authority. The EFSA Journal 1018:1-59; 2009.

Elish E, Karpas Z, Lorber A. Determination of uranium concentration in a single hair strand by laicpms applying continuous and single pulse ablation. Journal of Analytical Atomic Spectrometry 22: 540-546; 2007. DOI: 10.1039/b617396a

Finkelstein MM, Kreiger N. Radium in drinking water and risk of bone cancer in ontario youths: A second study and combined analysis. Occupational and Environmental Medicine 53: 305-311; 1996. DOI: 10.1136/oem.53.5.305

Gonnen R, Kol R, Laichter Y, Marcus P, Halicz L, Lorber A, Karpas Z. Determination of uranium in human hair by acid digestion and fias-icpms. Journal of Radioanalytical and Nuclear Chemistry 243: 559-562; 2000.

Hallstadius L. A method for the electrodeposition of actinides. Nuclear Instruments and Methods In Physics Research 223: 266-267; 1984. DOI: 10.1016/01675087(84)90659-8

Holm E. Review of alpha-particle spectrometric measurements of actinides. Int J Appl Radiat Is 35: 285-290; 1984. DOI: 10.1016/0020-708X(84)90070-X

International Commission on Radiological Protection. Metabolic data for uranium. Annals of the icrp 2: 102-104; 1979. DOI: 10.1016/0146-6453(79)90091-5

International Commission on Radiological Protection. Age-dependent doses to members of the public from intake of radionuclides: Part 3 ingestion dose coefficients. Ann icrp $25 ; 1995$.

Isam Salih MM, Pettersson HBL, Lund E. Uranium and thorium series radionuclides in drinking water from drilled bedrock wells: Correlation to geology and bedrock 
radioactivity and dose estimation. Radiat Prot Dosim 102: 249-258; 2002. DOI: 10.1093/oxfordjournals.rpd.a006093

Ivanovich M, Harmon RS. Uranium series disequilibrium - applications to environmental problems. Oxford: Oxford Science Publications; 1982.

Jia G, Torri G, Magro L. Concentrations of 238u, 234u, 235u, 232th, 230th, 228th, 226ra, 228ra, 224ra, 210po, 210pb and 212pb in drinking water in italy: Reconciling safety standards based on measurements of gross $\alpha$ and $\beta$. J Environ Radioactiv 100: 941949; 2009. DOI: 10.1016/j.jenvrad.2009.07.002

Karpas Z, Lorber A, Sela H, Paz-Tal O, Hagag Y, Kurttio P, Salonen L. Measurement of the $234 \mathrm{u} / 238 \mathrm{u}$ ratio by mc-icpms in drinking water, hair, nails, and urine as an indicator of uranium exposure source. Health physics 89 : 315-321; 2005b. DOI: 10.1097/01.HP.0000165450.76676.10

Karpas Z, Paz-Tal O, Lorber A, Salonen L, Komulainen H, Auvinen A, Saha H, Kurttio P. Urine, hair, and nails as indicators for ingestion of uranium in drinking water. Health physics 88: 229-242; 2005a. DOI: 10.1097/01.HP.0000149883.69107.ab

Kehagia K, Bratakos S, Kolovou M, Potiriadis C. Hair analysis as an indicator of exposure to uranium. Radiat Prot Dosim 144: 423-426; 2011. DOI: 10.1093/rpd/ncq324

Krause K, Foitzik K. Biology of the hair follicle: The basics. Seminars in Cutaneous Medicine and Surgery 25: 2-10; 2006. DOI: 10.1016/j.sder.2006.01.002

Leggett RW, Eckerman KF, McGinn C, Meck R. Controlling intake of uranium in the workplace: Applications of biokinetic modeling and occupational monitoring data. Oak Ridge National Laboratory (ORNL); 2012.

Li WB, Karpas Z, Salonen L, Kurttio P, Muikku M, Wahl W, Hollriegl V, Hoeschen C, Oeh U. A compartmental model of uranium in human hair for protracted ingestion of natural uranium in drinking water. Health Phys 96: 636-45; 2009. DOI: 10.1097/01.HP.0000345023.46165.1c

Mohagheghi AH, Shanks ST, Zigmond JA, Simmons GL, Ward SLA. A survey of uranium and thorium background levels in water, urine, and hair and determination of uranium enrichments by icp-ms. Journal of Radioanalytical and Nuclear Chemistry 263: 189195; 2005. DOI: 10.1007/s10967-005-0036-y

Muikku M, Heikkinen T. Exogenous contamination of uranium in human scalp hair. Health Phys 102: 699-703; 2012. DOI: 10.1097/HP.0b013e31824ac770

Muikku M, Puhakainen M, Heikkinen T, Ilus T. The mean concentration of uranium in drinking water, urine, and hair of the occupationally unexposed finnish working population. Health physics 96 : 646-654; 2009. DOI:

10.1097/01.HP.0000345026.98668.c4

Prat O, Vercouter T, Ansoborlo E, Fichet P, Perret P, Kurttio P, Salonen L. Uranium speciation in drinking water from drilled wells in southern finland and its potential links to health effects. Environmental Science and Technology 43: 3941-3946; 2009. DOI: $10.1021 / \mathrm{es} 803658 \mathrm{e}$

Rodushkin I, Axelsson MD. Application of double focusing sector field icp-ms for multielemental characterization of human hair and nails. Part ii. A study of the inhabitants of northern sweden. Sci Total Environ 262: 21-36; 2000. DOI: 10.1016/S0048-9697(00)00531-3 
Spencer H, Osis D, Fisenne IM, Perry PM, Harley NH. Measured intake and excretion patterns of naturally occurring $234 \mathrm{u}, 238 \mathrm{u}$, and calcium in humans. Radiation Research 124: 90-95; 1990.

Stadlbauer C, Prohaska T, Reiter C, Knaus A, Stingeder G. Time-resolved monitoring of heavy-metal intoxication in single hair by laser ablation icp-drcms. Anal Bioanal Chem 383: 500-508; 2005. DOI: 10.1007/s00216-005-3283-4

United Nations Scientific Commitee on the Effects of Atomic Radiation. Sources and effects of ionizing radiation. New York: United Nations; Annex B: Exposure from natural radiation sources; 2000

World Health Organisation. Guidelines for drinking-water quality, 4th ed. Geneva: World Health Organisation Press; Chapter 9: Radiological Aspects; 2011

Wrenn ME, Durbin PW, Howard B, Lipsztein J, Rundo J, Still ET, Willis DL. Metabolism of ingested $u$ and ra. Health physics 48: 601-633; 1985. DOI: 10.1097/00004032198505000-00004

Zamora ML, Zielinski JM, Meyerhof DP, Tracy BL. Gastrointestinal absorption of uranium in humans. Health physics 83: 35-45; 2002. DOI: 10.1097/00004032-200207000-00004

Zunic ZS, Tokonami S, Mishra S, Arae H, Kritsananuwat R, Sahoo SK. Distribution of uranium and some selected trace metals in human scalp hair from balkans. Radiat Prot Dosim 152: 220-223; 2012. DOI: 10.1093/rpd/ncs225Table 